Neuropsychobiology 1995;32:I-IV

Contents, Vol. 32, 1995

International Journal of Experimental and Clinical Research in Biological Psychiatry, Pharmacopsychiatry, Biological Psychology/Pharmacopsychology and

Pharmacoelectroencephalography

Founded 1975 by J. Mendlewicz (Brussels).

Since 1983 integrating 'International Pharmacopsychiatry',

founded 1968 by F.A. Freyhan (New York), N. Petrilowitsch (Mainz), P. Pichot (Paris)

Biological Psychiatry

Main Editor

J. Mendlewicz, Brussels

Pharmacopsychiatry

Main Editor B. Saletu, Vienna

Associate Editors

H. Beckmann, Würzburg

K. Rickels, Philadelphia, Pa.

Biological Psychology/ Pharmacopsychology

Main Editor

P. Netter, Giessen

Associate Editors

P.L. Carlton, Piscataway, N.J.

W. Janke, Würzburg

D.M. Warburton, Early Gate, Reading

Pharmacoelectroencephalography

Main Editor

W.M. Herrmann, Berlin

Associate Editors H. Heinze, Hannover M. Fink, St. James, N.Y. M. Saito, Osaka 
Advisory Board

V. Albrecht, Prague

J. Angst, Zurich

Th.A. Ban, Nashville, Tenn.

J. Bock, Basel

W. Boucsein, Wuppertal

M. Bourin, Nantes

N. Brunello, Milan

M.S. Buchsbaum, Irvine, Calif.

R. Carey, Syracuse, N.Y.

R. Cespuglio, Lyon

A. Coppen, Epsom

R. Coppola, Washington, D.C.

J.-M. Danion, Strasbourg

J.R. Davis, Chicago, 111.

G. Debus, Aachen

A. Delini-Stula, Lingolsheim

H. Depoortere, Bagneux

A.E. Dresse, Liège

G. Erdmann, Berlin

H.J. Eysenck, London

G. Ferber, Basel

U. Ferner, Basel

A. Friederici, Berlin

J. Fritze, Köln

J.-M. Gaillard, Chêne-Bourg

S. Givens, Nutley, N.J.

J. Glowinski, Paris

F.K. Goodwin, Bethesda, Md.

P. Grof, Hamilton, Ont.

O. Hagnell, Lund

U. Hegerl, Berlin

C.J. Heijnen, Utrecht

H. Heimann, Tubingen 
T. Helgason, Reykjavik

D. Hellhammer, Trier

I. Hindmarch, Guildford

T.M. Ml, New York, N.Y.

P. Janssen, Beerse

M. Jobert, Berlin

F.N. Johnson, Lancaster

M. Jouvet, Lyon

K.W. Kallus, Würzburg

H. Kleinlogel, Hinterkappelen

F. Krijzer, Weesp

St. Kubicki, Berlin

J. Kugler, Munich

D. Kupfer, Pittsburgh, Pa.

M. Lader, London

S.Z. Langer, Paris

D. Lehmann, Zurich

H. Lehnert, Magdeburg

G.A. Lienert, Nüraberg

P.T. Loosen, Nashville, Tenn.

J.J. Lopez Ibor, Madrid

H. Maier-Lenz, Sigmaringen

G.P. Mark, Portland, Oreg.

M. Matejcek, Basel

J. Mathieson, Nutley, N.J.

M. Matousek, Göteborg

N. Matussek, Munich

H.Y. Meltzer, Cleveland, Ohio

S. Montgomery, London

T.F. Münte, Hannover

H. Nyborg, Risskov

T. Ohta, Nagoya

K. Pawlik, Hamburg 
J.M. Perel, Pittsburgh, Pa.

C. Perris, Umeå

H. Petsche, Vienna

W. Pöldinger, Basel

R. Pohl, Detroit, Mich.

A.J. Prange, Chapel Hill, N.C.

Ch. Pull, Luxembourg

G. Racagni, Milan

J.D. Rainer, New York, N.Y.

M. Sandier, London

W.G. Sannita, Genova

N. Sartorius, Geneva

D. Schalling, Stockholm

R. Scherschlicht, Basel

R. Schlittgen, Hamburg

F. Schulsinger, Copenhagen

H. Schulz, Berlin

R. Schwarting, Düsseldorf

Ch. Shagass, Philadelphia, Pa.

R. Tissot, Geneva

H.M. Van Praag, Maastricht

M. Vartanian, Moscow

A. Villeneuve, Beauport, Que.

O. Vinar, Prague

W. Vogel, Philadelphia, Pa.

K.H. Voigt, Marburg

M. Vojtëchovsky, Prague

A. Wauqier, Toledo, Ohio

P. Willner, Swansea

G. Winokur, Iowa City, Iowa

B. Woggon, Zurich

H. Yamadera, Tokyo

MBH Youdim Haifa

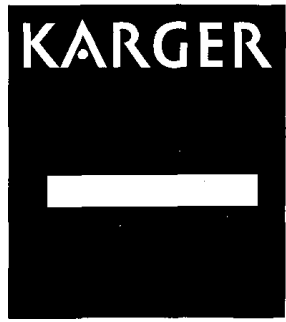


Acknowledgment

The editors and the publisher gratefully appreciate the expert help of the following reviewers:

Pharmacopsych $;$ atry

M. Ackenheil, Munich

M. Barbanoj, Barcelona

Ch. Barnas, Vienna

P. Baumann, Prilly

H. Beckmann, Würzburg

M. Campbell, New York, N.Y.

T. Crow, Harrow

M. Dietzel, Vienna

V. Filip, Prague

M. Fink, Stony Brook, N.Y.

P. Fischer, Vienna

K.P. Fischhof, Vienna

W. Fleischhacker, Innsbruck

M. Freissmuth, Vienna

J. Fritze, Cologne

L. Frölich, Frankfurt/Main

M. Gastpar, Essen

W. Herrmann, Berlin

O. Hornykiewicz, Vienna

S. Kasper, Vienna

J. Kornhuber, Würzburg

B. Küfferle, Vienna

G. Laakmann, Munich

L. Linzmayer, Vienna

H. Lübbert, Basel 
F. Müller-Spahn, Basel R. Schmid, Vienna H.V. Semlitsch, Vienna W. Sieghart, Vienna J. Simeon, Ottawa, Ont. Ch.

Simhandl, Vienna Ch. Stuppäck, Innsbruck J. Svestka, Brno S.

Wiesnagrotzki, Vienna

Biological Psychology/ Pharmacopsychology

J. Hennig, Giessen A. Hüppe, Würzburg M. Hüppe, Würzburg

H. Schulz, Erfurt E.M. Steinmeyer, Aachen M. Stern, Tubingen

P. Weyers, Würzburg W. Wittling, Eichstätt

Pharmacoelectroencephalography

F. Bes, Berlin

S. Kraemer, Berlin

S. Karger

Medical and Scientific Publishers Basel $\cdot$ Freiburg $\cdot$ Paris $\cdot$ London New York $\cdot$ New Delhi $\cdot$ Bangkok Singapore $\cdot$ Tokyo $\cdot$ Sydney 


\section{Drug Dosage}

The authors and the publisher have exerted every effort to ensure that drug selection and dosage set forth in this text are in accord with current recommendations and practice at the time of publication. However, in view of ongoing research, changes in government regulations, and the constant flow of information relating to drug therapy and drug reactions, the reader is urged to check the package insert for each drug for any change in indications and dosage and for added warnings and precautions. This is particularly important when the recommended agent is a new and/or infrequently employed drug. 


\begin{abstract}
All rights reserved.
No part of this publication may be translated into other languages, reproduced or utilized in any form or by any means, electronic or mechanical, including photocopying, recording, microcopying, or by any information storage and retrieval system, without permission in writing from the publisher or, in the case of photocopying, direct payment of a specified fee to the Copyright Clearance Center (see 'Information for Readers and Subscribers').

(C) Copyright 1995 by S. Karger AG, P.O. Box, CH-4009 Basel (Switzerland) Printed in Switzerland on acid-free paper by Thür AG Offsetdruck, Pratteln

II
\end{abstract}


Eonts $1.32,1995$

No. 1 
Biological Psychiatry

Sleep EEG Changes in Psychotic Disorders: Gender and

Age Effects

Keshavan, M.S.; Reynolds, C.F. Ill; Haas, G.; Miewald, J.M.;

Montrose, D.M.

Peripheral Serotonin in Alzheimer's Disease 9

Kumar, A.M.; Sevush, S.; Kumar, M.; Ruiz, J.; Eisdorfer, C.

Sodium-Magnesium Exchange in Erythrocyte Membranes 13

from Patients with Affective Disorders

Widmer, J.; Féray, J.-C; Bovier, P.; Hilleret, H.; Raffin, Y.; Chollet, D.; Gaillard, J.-M.; Garay, R.

Effect of Previous Antidepressant Therapy on the Growth 19

Hormone Response to Apomorphine

Pitchot, W.; Hansenne, M.; Moreno, A.G.; Ansseau, M.

Pharmacopsychiatry

Are There Any Differences in the Safety and Efficacy of 23

Brofaromine and Imipramine between Non-Elderly and Elderly Patients Groups with Major Depression?

Volz, H.-P.; Müller, H.; Möller, H.-J.

Biological Psychology/ Pharmacopsychology

Amnesia after Diazepam Infusion into Basolateral But Not 31

Central Amygdala oïRattus norvegicus de Souza Silva, M.A.; Tomaz, C.

Effect of Sabeluzole (R 58 735) on Memory Functions in 37

Patients with Epilepsy

Aldenkamp, A.P.; Overweg, J.; Smakman, J.; Beun, A.M.; Diepman, L.; Edelbroek, P.; Gutter, T.;

Mulder, O.G.; v.t. Slot, B.; Vledder, B.

Pharmacoelectroencephalography

Bivariate Global Frequency Analysis versus Chaos Theory. 45

A Comparison for Sleep EEG Data

Ziller, M.; Frick, K; Herrmann, W.M.; Kubicki, S.; Spieweg, I.;

Winterer, G.

Analysis of Event-Related Potentials: A Physiological Inter-

pretation

Hernández-Collados, A. 
Biological Psychiatry

Combined Cognitive-Behavioral, Psychopharmacological and 59 Nutritional Therapy in Eating Disorders.

1. Anorexia nervosa - Restricted Type

Brambilla, F.; Draisci, A.; Peirone, A.; Brunetta, M.

Combined Cognitive-Behavioral, Psychopharmacological and 64 Nutritional Therapy in Eating

Disorders.

2. Anorexia nervosa - Binge-Eating/Purging Type

Brambilla, F.; Draisci, A.; Peirone, A.; Brunetta, M.

Combined Cognitive-Behavioral, Psychopharmacological and 68 Nutritional Therapy in Bulimia nervosa Brambilla, F.; Draisci, A.; Peirone, A.; Brunetta, M.

P300 in Posttraumatic Stress Disorder 72

Charles, G.; Hansenne, M.; Ansseau, M.; Pitchot, W.; Machowski, R.; Schittecatte, M.; Wilmotte, J. The Association of the Serotonin Metabolite, 5-HIAA, to the 75 Lysosomal Enzyme N-Acetyl- $\beta$ Glucosaminidase Garvey, M.J.; Noyes, R.; Woodman, C; Laukes, C.

A Historical Case of Disseminated Chronic Tuberculosis 79

Nores, J.M.; Yakovleff, Y.

Pharmacopsychiatry

Pathophysiology and Psychopharmacology of Dementia - 81

A New Study Design. I. Diagnosis Comprising Subjective and Objective Criteria Schellenberg, R.; Todorova, A.; Dimpfel, W.; Schober, F.

Biological Psychology/Pharmacopsychology

Vitamin Supplementation for 1 Year Improves Mood

98

Benton, D.; Haller, J.; Fordy, J.

Pharmacoelectroencephalography

On the Choice of Recording Duration in Pharmaco-EEG

Studies

Jobert, M.; Schulz, H.; Jähnig, P.

Ill 
No. 3 
No. 4

Biological Psychiatry

Tardive Psychopathology

Swartz, CM.

Increased Frequency of the Extended or Ancestral Haplotype 120 B44-SC3O-DR4 in Autism

Daniels, W.W.; Warren, R.P.; Odell, J.D.; Maciulis, A.; Burger, R.A.; Warren, W.L.; Torres, A.R.

Effect of Acute Treatment with Sodium Valproate on Cate- 124

cholamine and Serotonin Synthesis in Mouse Cerebral Cortex Takebayashi, M; Motohashi, N.; Saito, H,

Kagaya, A.; Yamawaki, S.

EEG Sleep Characteristics in Dysthymia and Major Depres- 128

sive Disorder

Arriaga, F.; Cavaglia, F.; Matos-Pires, A.; Lara, E.; Paiva, T.

Serum Levels of Carnitine in Chronic Fatigue Syndrome: 132

Clinical Correlates Plioplys, A.V.; Plioplys, S.

Pharmacopsychiatry

Cerebral Perfusion, Electrical Activity and Effects of Seroton- 139

ergic Treatment in Obsessive-Compulsive Disorder.

A Preliminary Study

Molina, V.; Montz, R.; Pérez-Castejón, M.J.; Martín-Loeches, M.;

Carreras, J.L.; Calcedo, A.; Rubia, F.J.

Dose-Dependent Effects of Chronic Amphetamine Adminis- 149 tration in Local Cerebral Glucose

Utilization in Rat Huang, Y.-H.; Tsai, S.-J.; Yu, M.-F.; Wang, Y.-C; Sim, C.-B.

Biological Psychology/ Pharmacopsychology

Effects of Diazepam and Buspirone on Reaction Time of 156

Saccadic Eye Movements

Fafrowicz, M.; Unrug, A.; Marek, T.; van Luijtelaar, G.; Noworol, C; Coenen, A.

Effects of Cigarette Smoking on Performance in a Simulated 161 Driving Task Sherwood, N.

Pharmacoelectroencephalography

Standard Operating Procedure for the Registration and 166

Computer-Supported Evaluation of Pharmaco-EEG Data Versavel, M.; Leonard, J.P.; Herrmann, W.M.; the working team EEG in Phase $\Gamma$ of the CIPS

Smaller Auditory P300 Amplitude in Schizophrenics in

Remission

Rao, K.M.J.; Ananthnarayanan, C.V.; Gangadhar, B.N.;

Janakiramaiah, $\mathrm{N}$. 
Biological Psychiatry

Electron-Microscopic Investigation of Muscle Mitochondria 175 in Chronic Fatigue Syndrome Pliolpys, A.V.; Pliolpys, S.

Heart Rate and Blood Pressure Variability: Implications for 182 Psychiatric Research Yeragani, V.K.

Pharmacopsychiatry

Changes of Carbohydrate-Deficient Transferrin in Chronic 192

Aloholism

König, P.; Niederhofer, H.; Steurer, H.; Haller, R.; Wölfle, R.;

Fritzsche, H.; Weiss, P.

Biological Psychology/Pharmacopsychology

Extraversion and Alcohol: Eysenck's Drug Postulate Revisited 197 Rammsayer, T.

Pharmacoencephalography

Electrophysiology of the Visual System. From Neuroscience to 208 Human Neuropharmacology Sannita, W.G.

Mizolastine, a Novel Selective Histamine H1 Receptor Anta- 214 gonist: Lack of Sedative Potential on the EEG in the Rodent Depoortere, H; Decobert, M.; Granger, P.; Françon, D.

Author Index Vol. 32,1995 222

Subject Index Vol. 32, 1995223

I

IV 


\section{Contents}

